\title{
Ultrasonic constraint of the microfracture anisotropy of flysch rocks from the Podhale Synclinorium (Poland)
}

\author{
Agnieszka Kłopotowska ${ }^{1}$ D
}

Received: 5 April 2017 / Accepted: 21 December 2017 / Published online: 5 January 2018

(c) The Author(s) 2017. This article is an open access publication

\begin{abstract}
This paper attempts to show the relationship between joints observed in flysch formations in the field and microfracture fabrics invisible to the naked eye in hand specimens. Ultrasonic measurements demonstrate that the intensity and orientations of domains "memorised" by rock specimens are associated with the historical stresses within the rock mass rather than the rock lamination. The spatial orientations of these microfractures have been measured, and their dynamic-elastic properties have been found to correlate with the orientation of macroscopic joint sets measured in the field. The elastic properties measured vary because of sedimentary diagenetic processes that occured during the tectonic deformations of these flysch rocks in the Podhale Synclinorium of Poland. The structural discontinuities detected by ultrasonic measurements can be perceived as an incipient phase of the macroscopic joints already visible in the field and are attributed to the in situ residual tectonic stresses. Such historical stresses impart a hidden mechanical anisotropy to the entire flysch sequence. The microfractures will develop into macroscopic joints during future relaxation of the exposed rock mass. Understanding the nature and orientation of the invisible microfracture anisotropy that will become macroscopic in the future is vital for the safe and efficient engineering of any rock mass.
\end{abstract}

Keywords Joints $\cdot$ Microfractures $\cdot$ Flysch rocks $\cdot$ Ultrasonic waves $\cdot$ Dynamic elastic properties

\section{Introduction}

The mechanical properties of any rock mass must be known in appropriate detail to design safe and efficient future engineering projects in, on, or under it. For example, one can deduce the effective density of a rock mass when density varies inside it along specific directions (Mukherjee 2017a, b, c, 2018). Detailed investigations of the mechanical properties (e.g. Mukherjee et al. 2010; Mukherjee 2011, 2013; Mukherjee and Mulchrone 2012; Pinińska 2011) should follow routine analyses of the overall geological structure and hydrogeological conditions of the rock mass. Such studies should characterise the rock mass in terms of its mineralogical and petrographic characteristics as well as its structural heterogeneity, discontinuities and anisotropy of physical and mechanical properties (Thiel 1980). Typical rock properties required are the types, proportions and size of the constituent

Agnieszka Kłopotowska

a.klopotowska@uw.edu.pl

1 Faculty of Geology, Warsaw University, Warsaw, Poland minerals and their orientations together with the proportions, size and orientations of any pores and any cement filling them. The presence of discontinuities in the form of visible joints or hidden internal weaknesses such as microfractures reduces the overall strength of the rock mass, increases its deformability and permeability and facilitates the movement of rock blocks (Van der Pluijm and Marshak 2004; Pinińska and Dziedzic 2006; Domonik 2012).

Geologic fractures are generally thought to initiate at flaws randomly dispersed throughout the host rock (e.g. Olson 1993), based on the experimental works of Griffith (1921) as well as field evidence that joints propagated from microfractures located at fossils or sedimentary structures (e.g. Helgeson and Aydin 1991; Savalli and Engelder 2005). The issue of explaining fracture patterns, in particular how to start from an unorganised flaw distribution and produce a non-random pattern, is currently being investigated (Hooker et al. 2017). Kieslinger (1958) expressed the view that the presence of joints in the rock mass is primarily attributed to in situ residual tectonic stresses. Decrease of the overburden results in relaxation of the rock mass, which is manifested in the form of less or more advanced disintegration of the rocks 
into blocks. Furthermore, Boretti-Onyszkiewicz (1968a) interpreted such disintegration of rocks into blocks as a result of hidden, potential surface discontinuities. She found that the directions of increased stresses are as if "memorised" by the rock mass and are revealed in favourable circumstances for example during uniaxial compression tests or as the rock mass relaxes as it weathers. It should be noticed that most rocks experience several different stress regimes during their history with the result that several joint sets are frequently found superimposed on each other to produce a joint network. The complex stress history, which the Podhale Synclinorium has been subjected to, implies that the local rocks are predisposed to further degradation by more of the joints than those already observed; this in turn will increase its anisotropy of elasticity.

From a practical point of view, a penetrative fracture anisotropy is of crucial importance to the capacity of the rock mass to expand laterally. The rock blocks are mainly formed as a result of joint disclosure and the related expansion of rock masses, which is connected with the increase of rock mass capacity sideways with further advancement of the relaxation process as well as during weathering. Therefore the fracture anisotropy would be especially dangerous in slope and edge zones of valleys (Boretti-Onyszkiewicz 1968a).

This paper is a continuation of the geo-mechanical research on joints in the Polish Carpathian Mountains initiated by Boretti-Onyszkiewicz (1968a), Domonik (2003, 2005, 2008), Kłopotowska and Łukasiak (2017) as well as the studies on the evolution of the joint network in the Inner Carpathians (Boretti-Onyszkiewicz 1968b; Halicki 1963; Książkiewicz 1968; Ludwiniak 2006, 2010) and the Outer Carpathians (Rubinkiewicz 1996, 1998; Mastella and Zuchiewicz 2000; Mastella and Konon 2002; Śmigielski 2007). This paper also develops the subject of the relationship between joints and the elastic properties of rock masses, which has received plenty of attention by engineering geologists in recent years, especially to predict the mechanical competency of formations targeted for future hydrocarbon exploration (Gueguen and Schubnel 2003; Eyinla and Oladunjoye 2014). That subject concerns the assessment of the elastic properties of rock masses in the field (Vilhelm et al. 2010; Živor et al. 2011; Stan-Kłeczek et al. 2012; Stan-Kłeczek and Idziak 2013) and laboratory (Pinińska et al. 2015; Stan-Kłeczek and Idziak 2008; Shkuratnik et al. 2015; Stan-Kłeczek 2016). It also concerns comparing the results obtained from static and dynamic test methods (Mockovčiaková and Pandula 2003; Barton 2007; Najibi et al. 2015). The static strength moduli can be measured by loading cylindrical core samples of standard sizes to destruction while the dynamic strength moduli can be measured by the non-destructive ultrasonic testing presented in this work.
Dynamic rock parameters can also be obtained directly in outcrops using geophysical methods.

This paper aims to demonstrate the existence of a hidden anisotropy and the resulting variability of the rocks' dynamic elastic properties revealed by directional attenuation of ultrasonic waves. The work does not aim to establish a conversion factor between static and dynamic measurement. However, the results of the elastic properties derived from both static and dynamic methods are actually presented.

The study was conducted in the Podhale Synclinorium where well-developed joints are common in rocks that have been only slightly deformed by tectonic forces.

According to Hancock (1985) and Dunne and Hancock (1994), the label "joint" is a useful field term for a barren, closed fracture on which there is no measurable slip or dilation at the scale of observation. In this paper, the term "joint" refers to systematic penetrative fractures that are perpendicular to any layering (such as bedding), cut individual layers, and on which there is no measurable shear or dilatation offsets or having only a marked tendency for offset and with spacings roughly equal to the thickness of the host layer (Jaroszewski 1972; Mastella 1972; Dadlez and Jaroszewski 1994; Mastella and Zuchewicz 2000; Mastella and Konon 2002). Joint-related arrays of en echelon fractures have also been studied in the field. The term "microfractures", on the other hand, refers to high aspect ratio, lens or tabular-shaped cracks in rock, which are so small that it usually requires a microscope to detect them. Such microfracture fabrics are usually attributed to the effects of natural differential stresses. Microfractures commonly form as Mode I (opening) fractures where the minimum principal stress exceeds the elastic tensile strength creating a narrow opening displacement; in isotropic rocks, such fractures mark the plane perpendicular to the least compressive principal stress during fracture growth (Anders et al. 2014).

\section{Tectonic and geological setting}

The Podhale Synclinorium is a vast latitudinal trough in a Paleogene part of the Inner Carpathians (Fig. 1). Its northern limb borders the Pieniny Klippen Belt and its southern part is adjacent to Sub-Tatric units (Książkiewicz 1972). The synclinorium developed because of the inversion of a basin filled with Paleogene flysch during Miocene. In its southern limb, basal members of the Podhale succession are represented by shallow water, clastic and carbonate formations of the "nummulitic" Eocene (Roniewicz 1969; Żelaźniewicz et al. 2011). These beds are overlain by thick beds of a younger Podhale flysch (Watycha 1977; Książkiewicz 1972; Stupnicka 1997; Gedl 2000). This younger sequence has been divided into individual lithostratigraphic complexes based on the percentage of shale and sandstone beds 


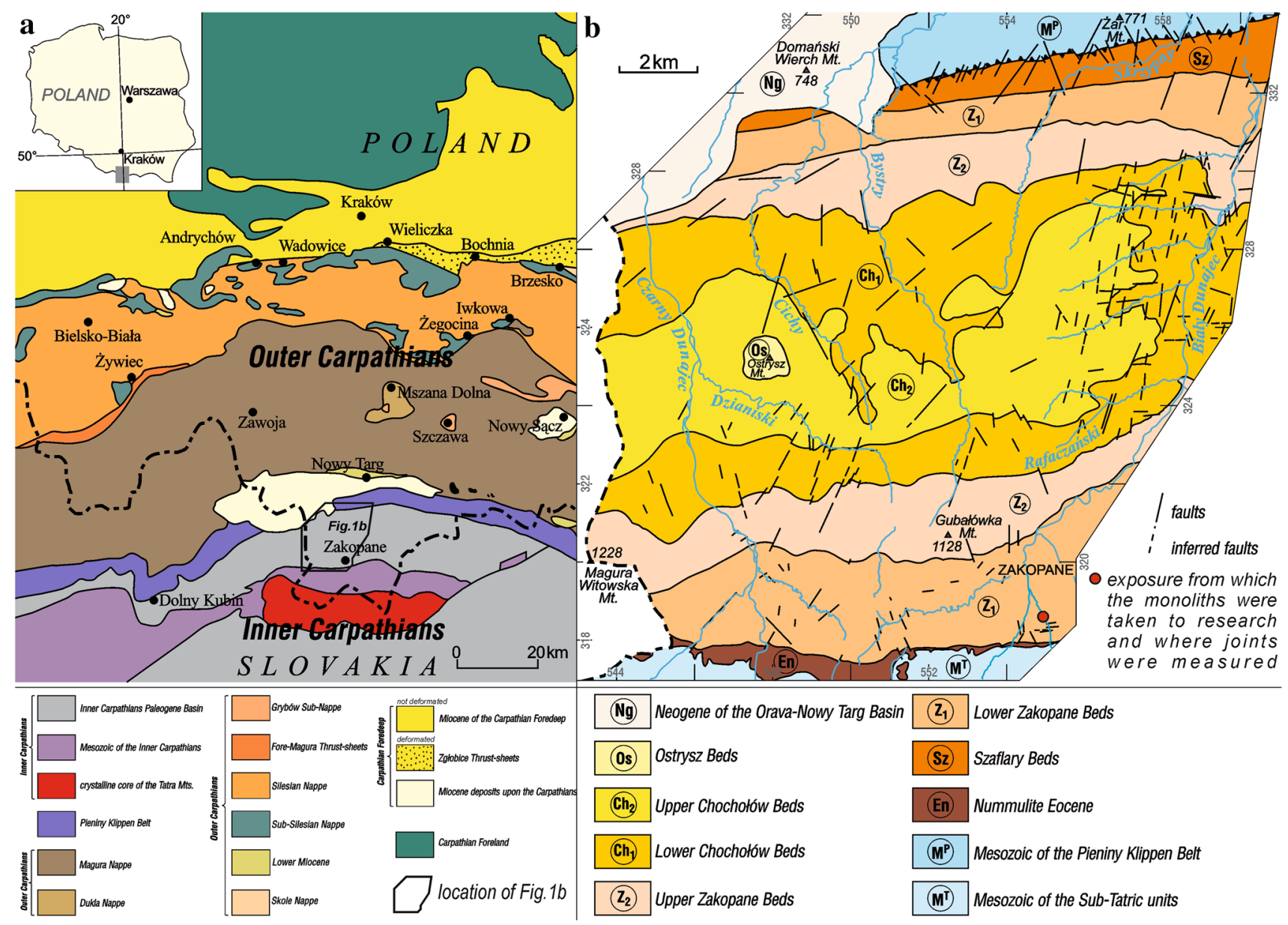

Fig. 1 a Fragment of the Polish Carpathians (based on Oszczypko et al. 2008, modified); b geological sketch map of the western Podhale Synclinorium (compiled after Watycha 1976; Mastella et al. 1988, 2000; Mastella and Klimkiewicz 2008; Ludwiniak 2008, modified)

following suggestion by Gołą (1959) and subsequently modified by Watycha $(1959,1968)$. According to this division, the Podhale flysch is divided into informal beds: Szaflary, Zakopane, Chochołów and Ostrysz.

The beds in the northern limb represent a monoclinal structure and dip generally southward at $10-25^{\circ}$. The most common bedding strikes in the eastern part of Western Podhale are 74-130 (Ludwiniak 2006; Mastella et al. 1988). The southern limb has also a monoclinal structure (Mastella and Mizerski 1977; Mastella and Ozimkowski 1979) with beds striking $70-90^{\circ}$ and dips changing southward from $5^{\circ}$ to $30^{\circ} \mathrm{N}$ (Ludwiniak 2010). However, dips can reach $40-50^{\circ} \mathrm{N}$ in the vicinity of the Tatra's border. The axis of synclinorium plunges westward at $8^{\circ}$ (Mastella and Mizerski 1977) into direction of $280^{\circ}$ in that part of Podhale (Ludwiniak 2010). The synclinorium is cut by regular joints network (Halicki 1963; Boretti-Onyszkiewicz1968a; Morawski 1972; Mastella and Mizerski 1977; Mastella and Ozimkowski 1979; Ludwiniak 2006, 2010). The particular joint sets, however, occurred in different stress fields. The newest Ludwiniak's research on geometry, morphology and the attitude of joints with respect to bedding as well as joint-related structures and veins occurring in the flysch rocks of Western Podhale showed that the local joint network have been developed in several stages connected with the structural evolution of the Podhale Synclinorium (Ludwiniak 2010, see Fig. 18 therein). It follows from theoretical considerations (e.g. Mandl 1988) that $S_{\mathrm{R}}$ and $S_{\mathrm{L}}$ sets were formed during the initial stage of the diagonal system development as "potential shear surfaces" in a triaxial, compressive stress field $\left(\sigma_{1}>\sigma_{2}>\sigma_{3}\right)$ in the form of initial microcracks. The "shear" nature of the initiation of diagonal joints manifests itself among others by smooth joint surfaces. Moreover, the geometry of joint-related arrays of en echelon fractures points to a tendency to strike-slip movement along these joints. In the discussed area, the process of formating of the oldest sets, i.e. $S_{\mathrm{R}}$ and $S_{\mathrm{L}}$ started when horizontal flysch strata became sufficiently lithified to enable the accumulation of stresses arising from NNE to SSW regional compression caused by the convergence of the European plate with the ALCAPA (Ludwiniak 2010 after; 
Oszczypko and Ślączka 1989; Csontos et al. 1992; Plašienka et al. 1997; Fodor et al. 1999; Zoetemeijer et al. 1999) and lasted to the Late Oligocene (Golonka et al. 2000). Therefore, the $\sigma_{1}$ and $\sigma_{3}$ axes were oriented horizontally and the $\sigma_{2}$ axis vertically. The regionally dominating direction of the $\sigma_{1}$ axis was in the $11-15^{\circ}$ class, while the $\sigma_{3}$ axis in class $101-105^{\circ}$ (Ludwiniak 2010). It should be mentioned that there is only limited field evidence to suggest that these joints started to develop within poorly lithified rocks (e.g. Mastella 1988; Mastella et al. 1997). The opening joints of the $S_{\mathrm{R}}$ and $S_{\mathrm{L}}$ sets took place later in the Late Oligocene/Early Miocene (Birkenmajer 1986), in the extensional mode, when residual stresses acted. The other sets of joint were formed as a result of the WNW-ESE extension connected with the uplift of the synclinorium and subsequent in consequence of stress relaxation in the rock masses during postorogenic uplift (Ludwiniak 2008).

\section{Materials and methods}

Eight rock-oriented monoliths were collected (using sledge hammer and crowbar) from beds of sandstone $10 \mathrm{~cm}$ thick cropping out in the Biały Stream near the town of Zakopane on the southern limb of the Podhale Synclinorium (Figs. 1, 2a, 4a). In lithostratigraphic terms, these formations classify as the lower Zakopane beds. These consist of continuous packets of dark clay or calcareous shale and dark grey mudstones separated by thin beds of sandstones with calcareous cements; there are also occasional sandstone beds thicker than $10 \mathrm{~cm}$ (Gołąb 1959; Ludwiniak 2006; Watycha 1959, 1968). Detailed laboratory tests were performed on fineand very fine-grained grey sandstones with abundant carbonate cement. Weakly sorted, poorly and averagely rounded grains of monocrystalline quartz are the dominant component of these detrital sandstones. There are also minor quantities of polycrystalline quartz, and fragments of quartz and carbonate rocks with occasional grains of partially altered plagioclases and muscovite laminae. The rock texture is random, solid and non-porous. The intergranular spaces are tightly filled by a polycrystalline calcite cement with local of clusters of crystalline pyrite cubes $100 \mu \mathrm{m}$ across. According to the Pettijohn's classification (Pettijohn et al. 1972), the Zakopane sandstone should be considered as sub-lithic or sub-arkosic arenite. Ultrasonic tests in the Laboratory of the Department of Geomechanics at the Faculty of Geology of Warsaw University were preceded by field measurements of joint orientations, style and their crosscutting relationships in the same beds of sandstone (Fig. 2a). The measurements are estimated to have been made by Meridian compass to an accuracy of $\pm 2^{\circ}$. The measurements covered about 100 surfaces of joints $\left(\sim 8 \mathrm{~m}^{2}\right)$ that were subsequently analysed in structural terms following the general rules of statistical studies (Mastella 1988; Rubinkiewicz 1998). As suggested by some authors, e.g. Dunne and Hancocok (1994), Twiss and Moores (2001) and Ludwiniak (2006), the division of joints into the sets was made directly in the field by observing the surface traces
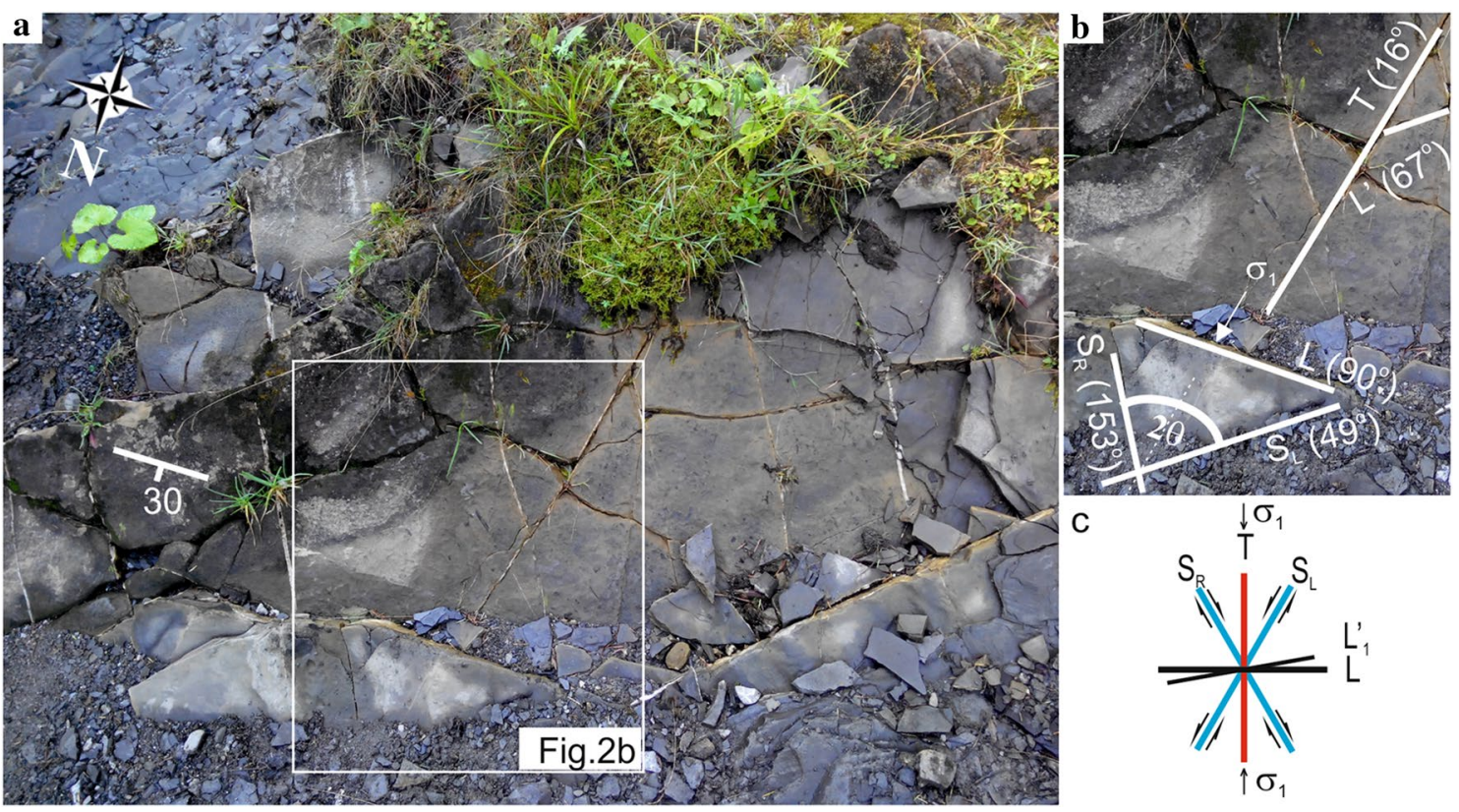

Fig. 2 a Joints in a Zakopane sandstone bed in the Biały Stream; b determination of the direction of the maximum stress axe $\left(\sigma_{1}\right)$; $\mathbf{c}$ scheme of the joint pattern in a sandstone bed 
of each set. Five sets of joints were recognised in the sandstone outcrops analysed. Specific sets were identified by their current orientation with respect to the regional extent of the Podhale Synclinorium (see Chap. 2). Of the five sets of joints, two sets are oblique to the axis of fold in which they are located and considered conjugate $\left(S_{\mathrm{R}}\right.$ and $\left.S_{\mathrm{L}}\right)$. Taking into account their arranged with respect to sedimentary layering and fold hinge lines, some researchers (e.g. Price 1967; Hancock 1985) named that system as conjugate $h k 0$ fractures enclosing an acute angle about the line parallel to sedimentary layering. There are also transverse $(T)$ and longitudinal $(L)$ sets named by the same authors as ac joints and $b c$ joints, (respectively) as well as sub-longitudinal $\left(L_{1}{ }^{\prime}\right)$ sets (Figs. 2b, 3c, 7a). In addition to joint orientation, the strike and dip of the beds in monoliths containing the joints were also measured with respect to north (Fig. 2a).

It was assumed that the most joint sets $S_{\mathrm{R}}$ and $S_{\mathrm{L}}$ had an initial pre-folding origin (Price 1959, 1966; Książkiewicz 1968; Jaroszewski 1972). In consequence, following Murray (1967) and Al Kadhi and Hancock (1980), the strata together with joints were back-tilted to the horizontal (Rubinkiewicz 1998; Mastella and Zuchiewicz 2000; Mastella and Konon 2002; Ludwiniak 2006). The statistics of the joint measurements were analysed using Tectonics FP specialist software for Structural Geology written by Franz Reiter and Peter Acs (Fig. 3). The mode orientations of individual joint sets were determined using contoured stereonets. It was deduced that the $S_{\mathrm{R}}$ set strikes at $138-159^{\circ}$ (with dominant $153^{\circ}$ ) and the $S_{\mathrm{L}}$ set at $46-58^{\circ}$ (with dominant $48^{\circ}$ ). The dihedral acute angle between $S_{\mathrm{R}}$ and $S_{\mathrm{L}}$ sets is $75^{\circ}$ (Fig. 3c, d). Following Bucher (1920, 1921) and Ramsay and Huber (1984), the dihedral acute angle between $S_{\mathrm{R}}$ and $S_{\mathrm{L}}$ sets represents the double value of the shear angle (20). The bisector of this angle marks the position of the maximum compression axis $\sigma_{1}$. Hence, the orientation of the axis of maximum compressive stress

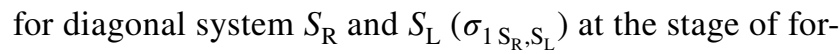
mating joints was deduced as $11^{\circ}$. The other sets of joints strike at $6-24^{\circ}\left(\right.$ with dominant $13^{\circ}$ ) for $T$ set, at $82-105^{\circ}$ (with dominant $88^{\circ}$ ) for $L$ set and at $62-78^{\circ}$ (with dominant $70^{\circ}$ ) for L' set (Fig. 3c, d).

Taking into account fracturing at an initial pre-folding phase, the genesis of the most sets of joints are interpreted following Price (1959, 1966), Książkiewicz (1968) and Jaroszewski (1972). This implies that the directions of principle normal and shear stresses "memorised" by rock mass (Boretti-Onyszkiewicz 1968a) manifest themselves in the form of structural weaknesses in core samples drilled out of the rock monoliths perpendicular to the bedding (as shown in Fig. 4b). This direction of drilling was also chosen in order to exclude other factors like directional placement of grains, high porosity or lamination that could cause anisotropy of elastic properties of the sandstones. To determine whether the grains were

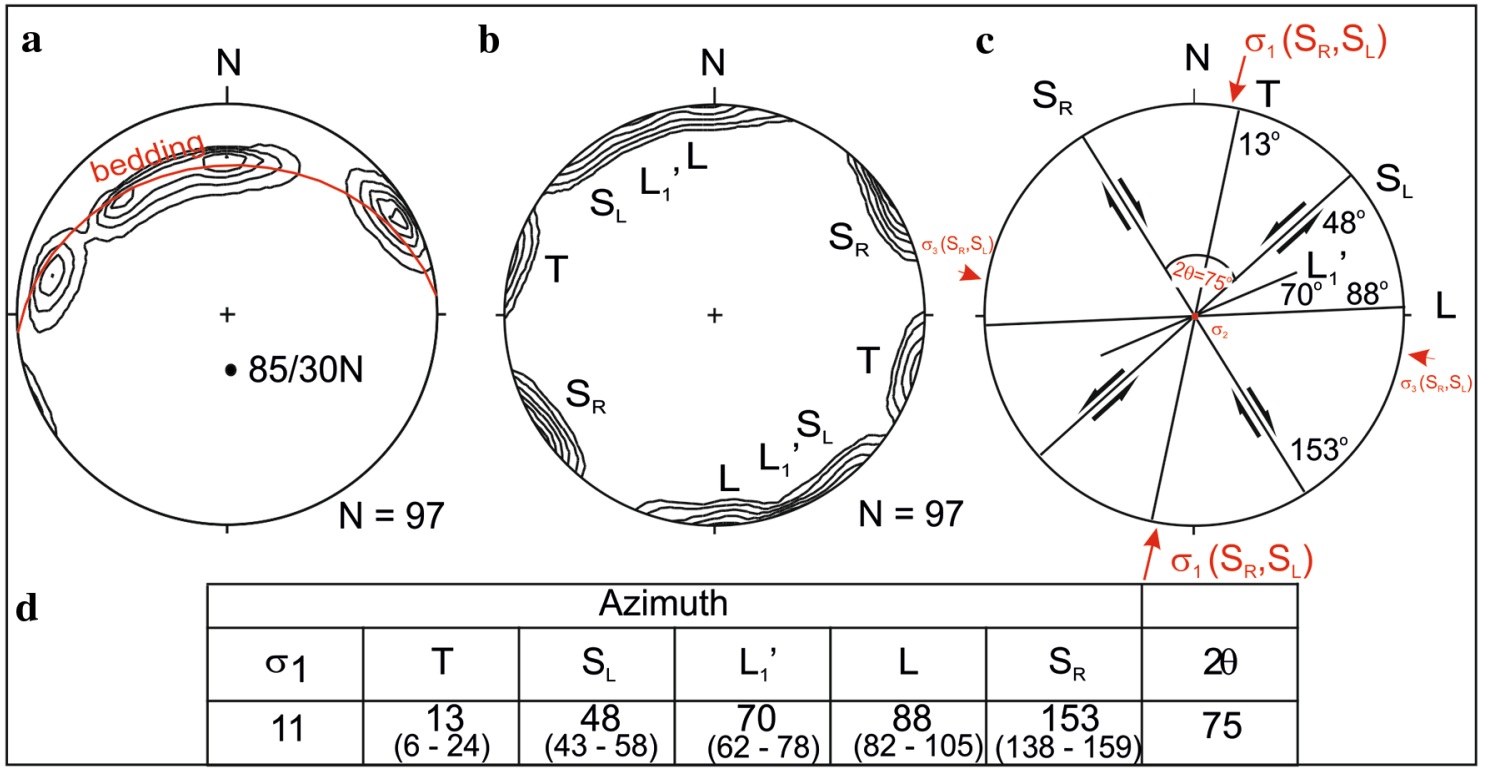

Fig. 3 Technique of determining the dominating directions and parameters of the joint network based on measurements in a Zakopane sandstone bed in the Biały Stream $(N$-number of measurements). a Diagrams with contours of joint planes before back tilting of beds to horizontal (recent position of joints); dot—pole to bedding plane; $\mathbf{b}$ the same diagram after bedding correction; $\mathbf{c}$ directions of joint sets inferred from dominants of $\mathbf{b}$ (values of azimuths of the dominating directions of sets are given; the arrows indicate offset along the diagonal system; shear system: $S_{\mathrm{R}}$ - dextral, $S_{\mathrm{L}}$ - sinistral; $T$-transversal; $L$ and $L^{\prime}$-longitudinal sets; $2 \Theta$-double value of shear angle; $\sigma_{1(\mathrm{SR}, \mathrm{SL})}$ - maximum compressive stress axis for diagonal system $S_{\mathrm{R}}$ and $S_{\mathrm{L}}$ ); d selected parameters of joint network 

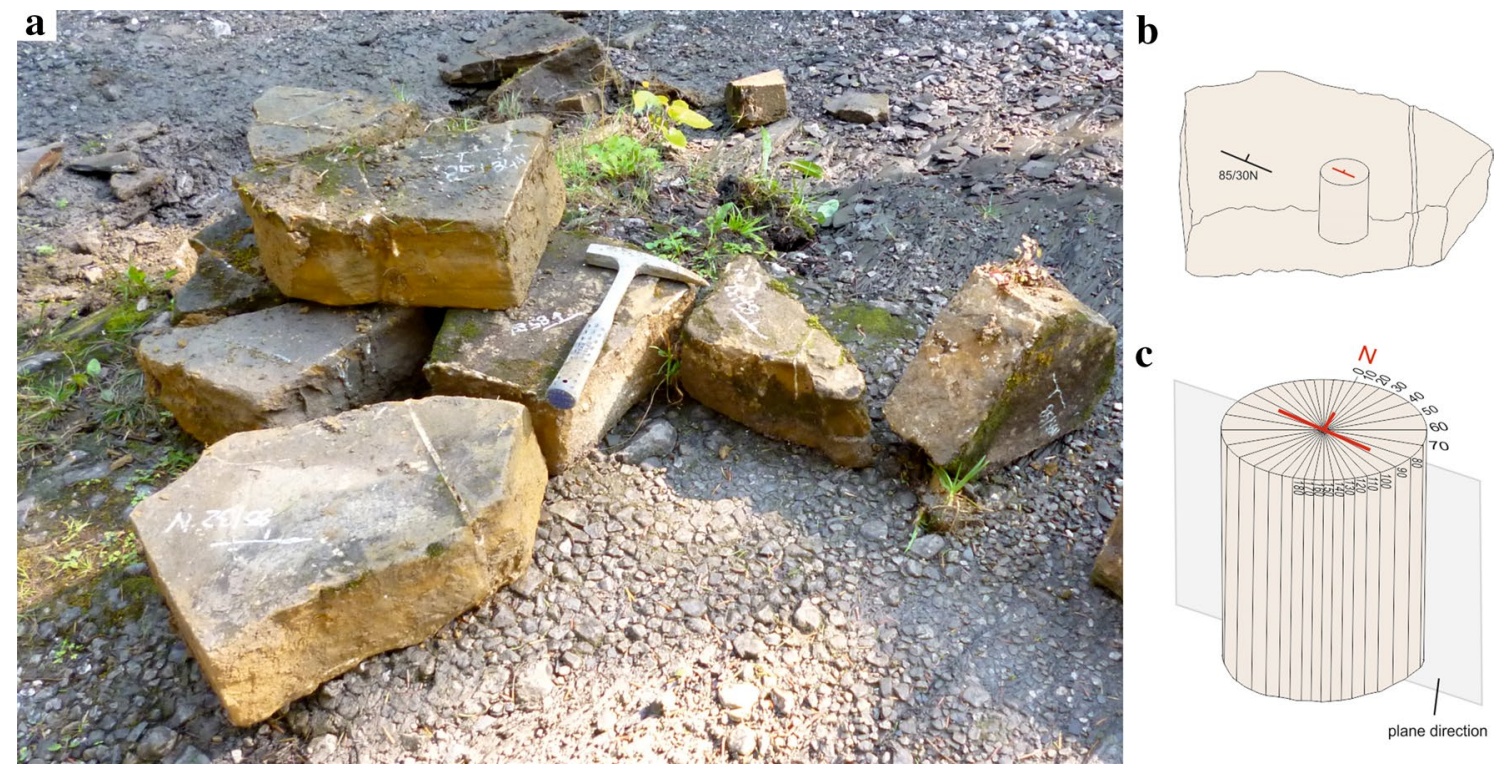

Fig. 4 Methodology of ultrasonic tests (Domonik 2007, modified): a rock monoliths from which the samples were cut to the laboratory tests; b orientation of cylindrical sample within rock monolith; c spatial orientation of measuring planes along with the directions of measurement of ultrasonic waves

procedure was repeated 18 times. The last one measurement consisted of applying the heads across the sample at its vertical axis. Altogether 19 measurements were made per sample.

Using the ultrasonic tests, the variability of the internal composition of rock material can be determined. It is due to the fact that pores, laminae, microfractures, directional placement of mineral grains and other heterogeneities of the internal composition are reflected by the variability of the ultrasonic wave propagation. The propagation of artificially generated ultrasonic elastic waves through the rock samples allows, not only the detection of defects and their spatial distribution in the sample, but also the characterisation of the spatial variations in dynamic elastic properties they impose. Each microfracture that was perpendicular or inclined at a high angle to the beam suppresses or entirely mutes the wave pulse that would normally be present in an area without defects (Domonik 2007).

The diagnosis of the anisotropy is most commonly based on the determination of the velocity of propagation of longitudinal $\left(V_{\mathrm{p}}\right)$ and shear waves $\left(V_{\mathrm{s}}\right)$, which in turn make it possible to calculate the dynamic modulus of elasticity $\left(E_{\mathrm{d}}\right)$ and dynamic Poisson's ratio $\left(v_{\mathrm{d}}\right)$-constants characterising the elastic properties of solid bodies (Burger 1992). Therefore, $E_{\mathrm{d}}$ was calculated using Eq. (1).

$E_{\mathrm{d}}=\rho \times V_{\mathrm{s}}^{2} \frac{\left(3 V_{\mathrm{p}}^{2}-4 V_{\mathrm{s}}^{2}\right)}{\left(V_{\mathrm{p}}^{2}-V_{\mathrm{s}}^{2}\right)}$, 
while $v_{\mathrm{d}}$ was calculated using Eq. (1)

$\nu_{\mathrm{d}}=\frac{V_{\mathrm{p}}^{2}-2 V_{\mathrm{s}}^{2}}{2\left(V_{\mathrm{p}}^{2}-V_{\mathrm{s}}^{2}\right)}$,

where $\rho$ is the bulk density of a rock $\left[\mathrm{kg} / \mathrm{m}^{3}\right]$, and $V_{\mathrm{p}}$ and $V_{\mathrm{s}}$ are velocities of longitudinal and shear wave, respectively $[\mathrm{m} / \mathrm{s}]$.

\section{Results}

The measured velocity of the ultrasonic waves depended on the direction of measurement as illustrated in Fig. 5. The maximum values of the longitudinal wave measured across the sample diameter $\left(V_{\mathrm{p}_{-} \mathrm{D}}\right)$ and the minimum measurements of the shear wave $\left(V_{\mathrm{S}_{-} \mathrm{D}}\right)$ were observed and listed in the following geographic directions measured from north: $10^{\circ}, 50^{\circ}, 70^{\circ}, 90^{\circ}, 110^{\circ}-120^{\circ}$ and $140^{\circ}-150^{\circ}$. Except for $110^{\circ}-120^{\circ}$, these directions correspond to the ranges of values assumed for joint sets measured in the field: $T$, $S_{\mathrm{L}}, L_{1}{ }^{\prime}, L$ and $S_{\mathrm{R}}$, respectively (Fig. 3c). The longitudinal waves that travelled parallel with the macroscopic joint surfaces were much less attenuated (and hence had higher wave velocities Fig. 5a), and the shear wave velocities were attenuated much more (and hence have smaller wave velocities Fig. 5b).

The dynamic Poisson's ratios calculated from these velocities are like those observed for $V_{\mathrm{p}}$. The dispersions of the $v_{\mathrm{d}}$ values are significant for all adopted measurement directions; the highest values are measured parallel to the joint sets measured in the field (Fig. 6a). Directional variations in the velocity of longitudinal waves $\left(V_{\mathrm{p}}\right)$ and shear waves $\left(V_{\mathrm{s}}\right)$ along with bulk density $(\rho)$ calculated for each sample result in corresponding variations in the distributions of the dynamic modulus of elasticity $\left(E_{\mathrm{d}}\right)$. Therefore, the elastic properties have a similar anisotropy to the individual directions of measured values of $V_{\mathrm{p}}$ (Fig. 6b). The highest $E_{\mathrm{d}}$ values were obtained in the directions that are within the range of the orientations interpreted for joint sets $T, S_{\mathrm{L}}, L_{1}{ }^{\prime}$, $L$ and $S_{\mathrm{R}}$.

The elastic properties were also assessed using static strength tests. The elastic properties were calculated along the sample length and compared with the dynamic values computed in the same direction. Each of the static $\mathbf{a}$

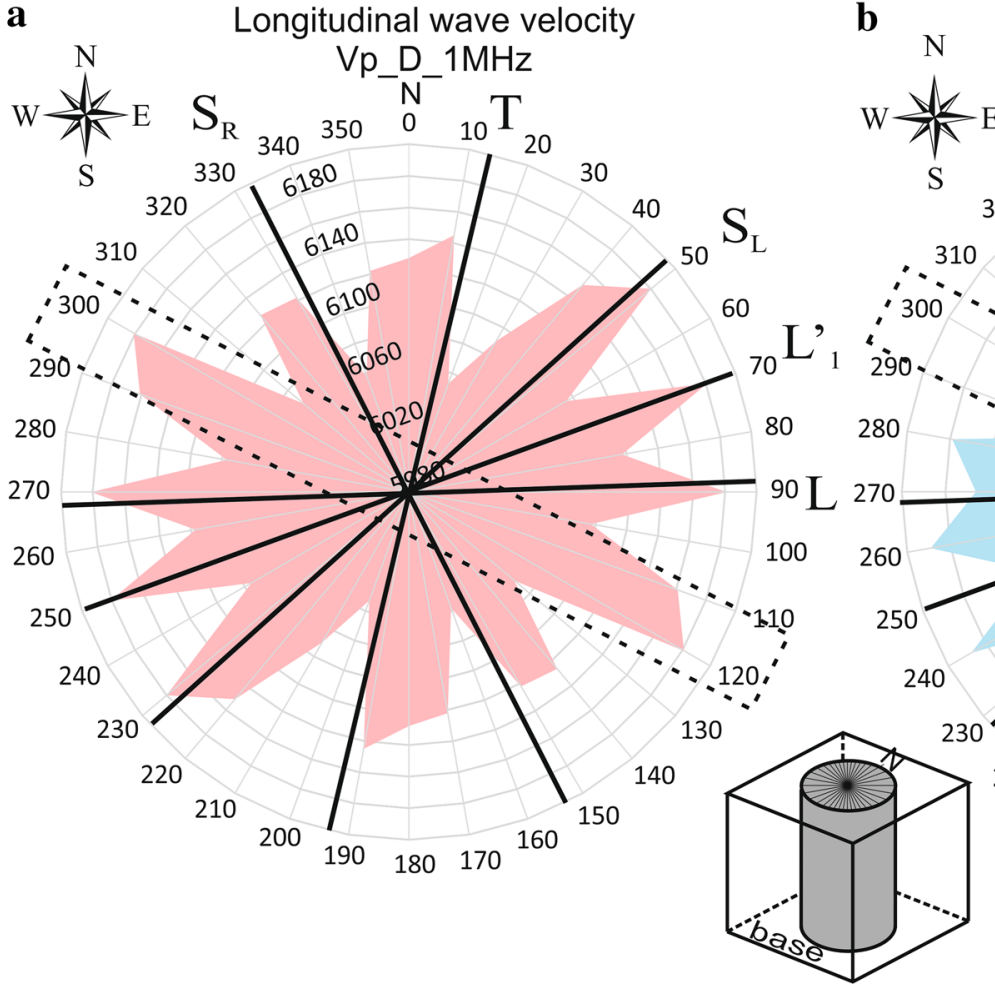

b Shear wave velocity

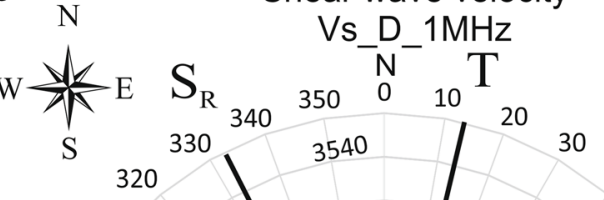

320

40 . 


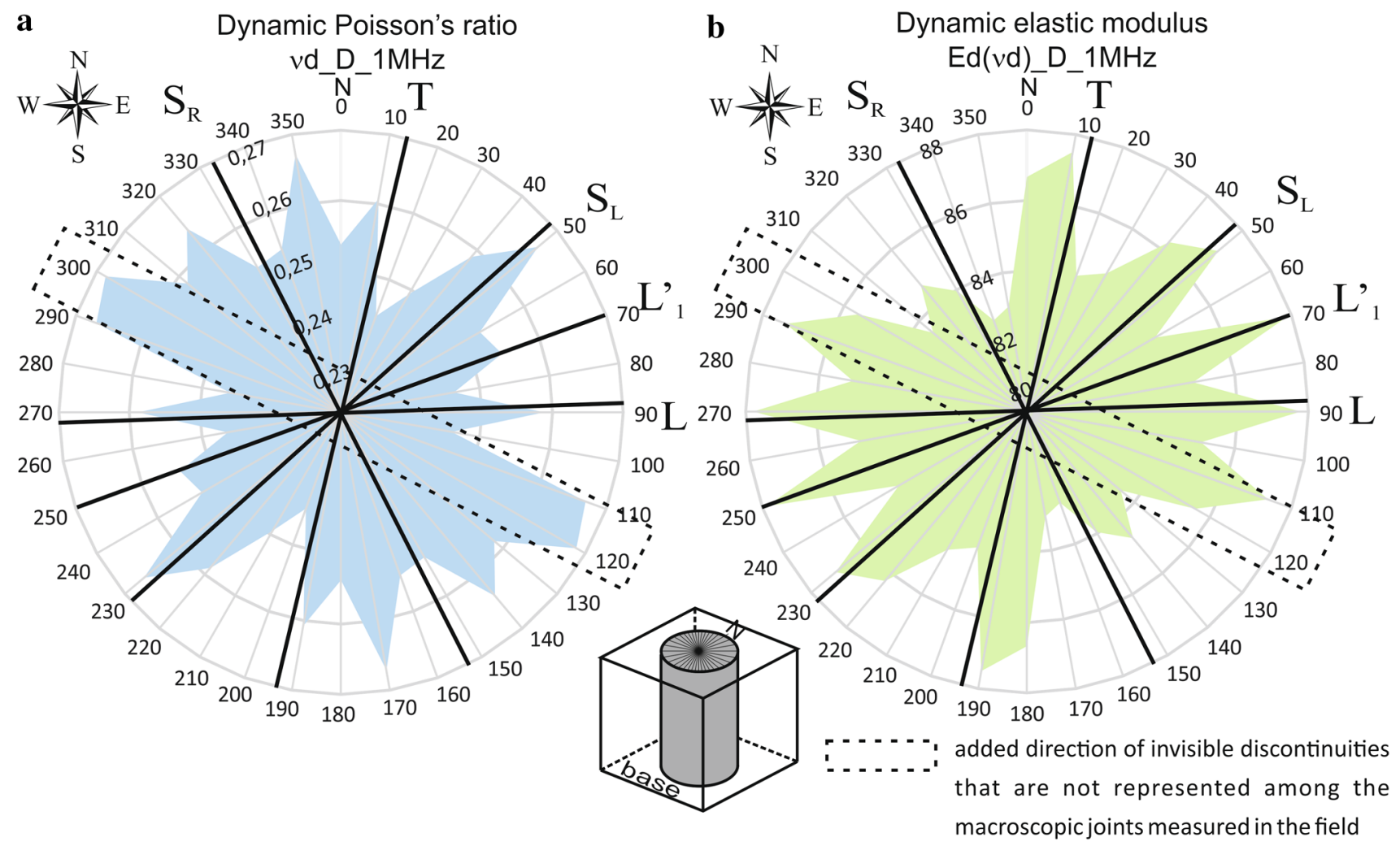

Fig. 6 Diagrams of distribution of dynamic elastic properties in oriented Zakopane sandstone depending on measuring directions against joint set dominants determined in the field drawn for arithmetic mean

Table 1 Results of elastic properties from uniaxial compression and ultrasonic tests on Zakopane sandstone

\begin{tabular}{lllll}
\hline Values & $E_{\mathrm{d}}[\mathrm{GPa}]$ & $v_{\mathrm{d}}[-]$ & $E_{\mathrm{st}}[\mathrm{GPa}]$ & $v_{\mathrm{st}}[-]$ \\
\hline Minimum & 71.2 & 0.16 & 61.6 & 0.12 \\
Average & $\mathbf{7 5 . 1}$ & $\mathbf{0 . 2 0}$ & $\mathbf{7 0 . 9}$ & $\mathbf{0 . 2 3}$ \\
Maximum & 78.8 & 0.23 & 75.7 & 0.29 \\
\hline
\end{tabular}

$E_{d}$ dynamic modulus, $v_{d}$ dynamic Poisson's ratio, $E_{s t}$ static modulus, $v_{s t}$ static Poisson's ratio

measurements is close to the equivalent dynamic measurements (Table 1).

\section{Conclusions}

In previous works, e.g. (Boretti-Onyszkiewicz 1968b; Halicki 1963; Książkiewicz 1968), mainly statistical methods were applied during the analysis of the joint direction. The issue of subdivision of the joint network into sets through observation of the morphology of joint traces as well as crosscutting relationships was not considered. It resulted in including joints having similar directions but different values of 69 samples: a dynamic Poisson's ratio; b dynamic elastic modulus (dynamic Young's modulus)

morphological features and different origins (e.g. $S_{\mathrm{L}}$ and $L_{1}{ }^{\prime}$ or $S_{\mathrm{R}}$ and $T$ ) into one set, which in turn effects in a too wide range of directions of particular sets. Ludwiniak (2006, 2010) reviewed some of the opinions included in the aforementioned works, which was a great progress. It was possible due to his own more thorough measurements in individual outcrops. Among other things, Ludwiniak noticed, for example, that none of the above-mentioned authors distinguished the set $T$, despite the fact that there were many outcrops in situ, where this set occurred (although in less quantity than sets $S_{\mathrm{R}}$ and $S_{\mathrm{L}}$ ). Moreover, insightful observations of the joint networks in the field, as suggested by Dunne and Hancocok (1994) as well as Twiss and Moores (2001), allowed the researcher to determine the origin of the joint network (five sets) in the Western Podhale region and reconstruct the paleo-stresses responsible for its development. On the other hand, Domonik $(2003,2005)$ determined only four sets of joints in the field ( $S_{\mathrm{R}}, S_{\mathrm{L}}, T$ as well as $L$ ), while not at all determining the $L^{\prime}$ set. The $L^{\prime}$ set was probably included in the adjacent $S_{\mathrm{L}}$ set. The joint sets determined this way could influence the assessment of the results of the strength as well as the ultrasonic tests. Domonik has in fact determined the acoustic and mechanical anisotropy, however, only for the above-mentioned four sets. Perhaps the 
subtle variations of wave velocity were omitted, which could suggest the existence of additional planes of microfractures.

The directional variability of elastic properties in the sandstone specimens analysed demonstrates a strong anisotropy due primarily to the effects of the stress presumed to have been active during the folding in the Late Oligocene/Early Miocene (Birkenmajer 1986) and the uplift of the Carpathian Mountains which started in the Middle Eocene (Środoń et al. 2006). This relationship is reinforced by the distribution of orientations of the macroscopic joint sets measured in the field being so like the orientations of microfractures in samples of rock that look isotropic to the eye. Keep in mind that the ultrasonic tests were carried out along 18 diametric paths only $10^{\circ}$ apart but the field measurements were estimated to an accuracy of $\pm 2^{\circ}$. This means that the value of dihedral angle may turn out to be slightly higher than in the field measurements. The velocities of the ultrasonic waves varied only with their direction of measurement. All variations in velocity (of the order of several tens of $\mathrm{m} / \mathrm{s}$ ) were taken as directly due to the internal structure of the tested sample. They were not due to changing measurement conditions, nor erroneous or accidental measurements. Similar relationships were observed in research on the Krosno sandstones from Mucharz (Dziedzic 2005). Therefore, it seems that measurements of the ultrasonic wave velocities through rock need to be only presented to an accuracy of the order of several tens of $\mathrm{m} / \mathrm{s}$ at the maximum $(100 \mathrm{~m} / \mathrm{s})$, as is usual in the literature.

In addition, structural discontinuities detected by ultrasonic measurements should be regarded as an incipient phase of a joint sensu stricto observed in situ. The same hidden joint anisotropy affects the entire flysch rock mass (Boretti-Onyszkiewicz 1968a). Domains in which elastic energy has accumulated will become increasingly obvious as they degrade during further relaxation of the historical stresses preserved in the rock mass.

The distribution of dynamic elastic constants revealed by the ultrasonic wave velocity measurements added the $110^{\circ}-120^{\circ}$ direction of invisible discontinuities that are not represented among the macroscopic joints measured in the field. It is possible that the additional set of microfractures is a joint set conjugate with a low dihedral angle and with a bisector approximately parallel to the axis of the syncline and was produced within longitudinal joints $(L)$ (Aleksandrowski 1989 after; Książkiewicz 1968). According to De Sitter (1964), such a system can develop where a syncline is horizontally shortened with the $\sigma_{1}$ axis parallel to the syncline axis and $\sigma_{3}$ perpendicular to it (Fig. 7). Therefore, the "hidden" direction of microfractures disclosed by ultrasonic measurements, and "memorised" by the rock mass, could represent the complementary sub-longitudinal set $\left(L_{2}{ }^{\prime}\right)$ and together with $L_{1}{ }^{\prime}$ set produce a conjugate system named as conjugate $h k 0$ fractures enclosing an acute angle about the line parallel to the fold axis (Price 1967; Hancock 1985). This system was produced at a different stress field than $S_{\mathrm{R}}$ and $S_{\mathrm{L}}$ conjugate joints.

The absence of macroscopic $L_{2}{ }^{\prime}$ joints in the field may be because both sets of conjugate joints do not always develop with equal intensity and it is not uncommon for one conjugate set of fractures to develop better that the other. Szichin (1960) suggested that a slightly earlier shear plane may have "delayed", hindered or even prevented the formation of the other. Conjugate shears can also result from the influence of a strong anisotropy in the failing medium (Jaroszewski 1974). The influence of a planar anisotropy (foliation) on the shear surfaces formed in static strength tests have been reported by, among others, Jaeger (1960), Donath (1961), Paterson $(1958,1978)$. These authors demonstrated that, if the mechanical anisotropy in the sample is strong, one of the two potential sets of shear surface develops along the weakest plane; meanwhile, the complementary shear plane either does not develop at all, or only develops poorly at an increased but still acute angle to its conjugate partner. It, therefore, seems reasonable to expect that the $110^{\circ}-120^{\circ}$ discontinuities "memorised" by the rock mass will eventually activate with further relaxation of the rock mass caused by other factors as weathering, mining, earthquakes or faulting.

It is also worth noting that as found by Boretti-Onyszkiewicz (1968a), strength tests conducted on the same apparently isotropic samples demonstrated the orientation of a hidden mechanical anisotropy and oriented similarly as the regional set of joints which she measured in the field. However, the direction range of the measurements conducted in the field was too wide so the directions obtained in the strength tests were, therefore, grouped into wrong sections.

The author of this work attempted to combine the current knowledge about the evolution of joint networks in the Polish Carpathian Mountains and the rules of field data gathering with the possibility of applying and developing geo-mechanical tests for joint anisotropy. This approach allowed confrontation of the field tests results with the results of the tests conducted in the laboratory, which in turn enabled discovery of new directions of potential internal weaknesses that are not represented among the macroscopic joints measured in the field.

The results of the research reported here indicate that ultrasonic measurements can accurately determine the internal mechanical heterogeneities in the elasticity of the rock mass and constrain its in situ stress field. This knowledge can be used, e.g. for the safe design of a tunnel lining and its interaction with the rock mass (Furtak 2004) as well as design stable slopes and excavations in flysch formations. However, it should be borne in mind that ultrasonic methods alone are not sufficient to determine the 


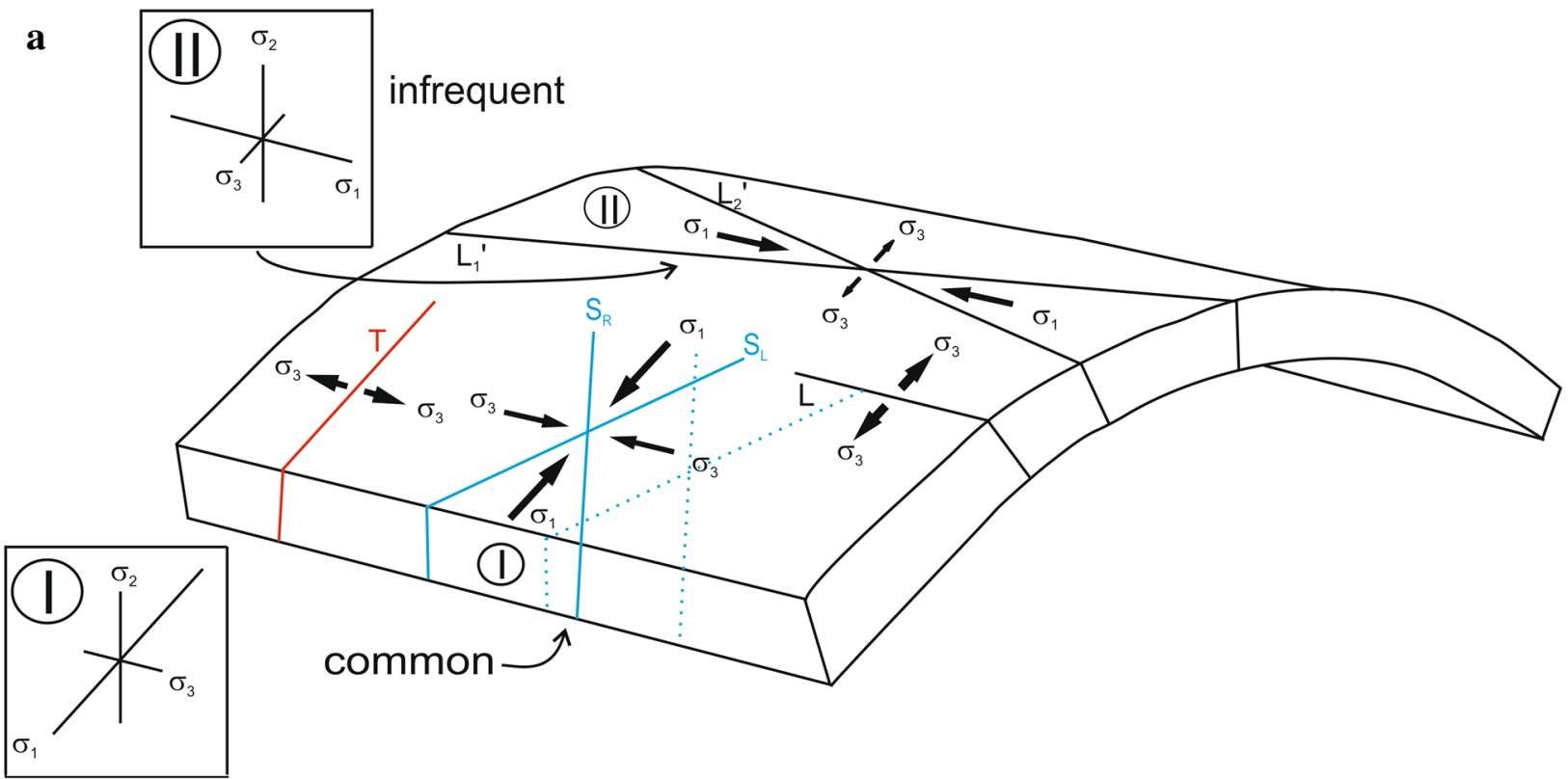

b

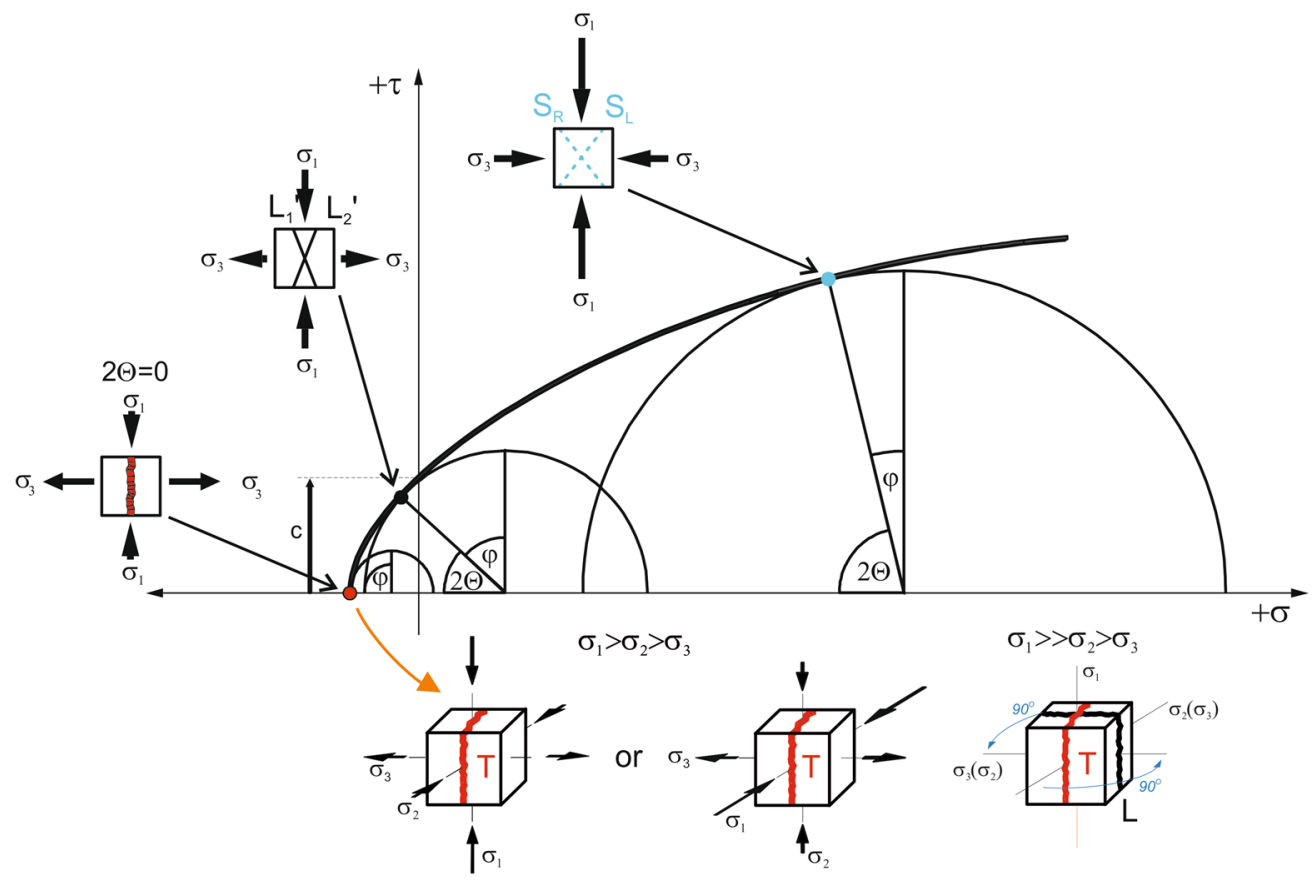

Fig. 7 a Typical relationship to a fold and orientation of extensional (dilational) and shear joints in a thin, bedded layer, with associated stress systems (Price and Cosgrove 1990, modified); b theoretical Mohr's diagram showing stress condition for development of the joint network according to ultrasonic test (Ludwiniak 2010 after; Price and

geo-mechanical parameters of any rock mass intended for sophisticated engineering.

Acknowledgements I would like to express my appreciation to Chris Talbot for improving the English and encouraging further research. Thanks to John Hooker, Ashok Yadav and Soumyajit Mukherjee for their valuable comments and suggestions concerning this manuscript.
Cosgrove 1990; Dadlez and Jaroszewski 1994, modified). $\varphi$-angle of internal friction, c-cohesion, $\tau$ - shear stress, $2 \theta$-double value of shear angle, opened joints are indicated as solid lines and initial microcracks as dashed ones

The research reported in this paper was funded by the statutory research fund of the Faculty of Geology of Warsaw University (BST_-173501).

Open Access This article is distributed under the terms of the Creative Commons Attribution 4.0 International License (http://creativecommons.org/licenses/by/4.0/), which permits unrestricted use, distribution, and reproduction in any medium, provided you give appropriate 
credit to the original author(s) and the source, provide a link to the Creative Commons license, and indicate if changes were made.

\section{References}

Al Kadhi A, Hancock PL (1980) Structure of the Durma-Nisah segment of the central Arabian graben system. Saudi Arab Dir Gen Miner Res Bull 16:1-40

Aleksandrowski P (1989) Geologia strukturalna płaszczowiny magurskiej w rejonie Babiej Góry. Stud Geol Pol 96:1-140 (in Polish with English summary)

Anders MH, Laubach SE, Scholz CH (2014) Microfractures: a review. J Struct Geol 69(Part B):377-394. https://doi. org/10.1016/j.jsg.2014.05.011

Barton N (2007) Rock quality, seismic velocity, attenuation, and anisotropy. Taylor \& Francis, London, pp 1-729

Birkenmajer K (1986) Stages of structural evolution of the Pieniny Klippen Belt, Carpathians. Stud Geol Pol 88:7-32

Boretti-Onyszkiewicz W (1968a) Joint anisotropy of flysch sandstones of West Podhale in the light of studies on strength. Biuletyn Geologiczny UW 10:115-152 (in Polish with English summary)

Boretti-Onyszkiewicz W (1968b) Jointing in the Flysch of Western Podhale. Acta Geol Pol 18:101-152 (in Polish with English summary)

Bucher WH (1920) The Mechanical Interpretation of joints. Part 1. J Geol 28(8):707-730

Bucher WH (1921) The mechanical interpretation of joints. Part 2. J Geol 29(1):1-28

Burger HR (1992) Exploration geophysics of the shallow subsurface. Prentice Hall PTR, Upper Saddle River, New Jersey, pp 1-489

Csontos L, Nagymarosy A, Horvath F, Kovač M (1992) Tertiary evolution of the Intracarpathian area: a model. Tectonophysics 208:221-241. https://doi.org/10.1016/0040-1951(92)90346-8

Dadlez R, Jaroszewski W (1994) Tektonika. Wydawnictwo Naukowe PWN, Warszawa, pp 1-743

De Sitter LU (1964) Structural geology, 2nd edn. McGraw Hill, New York, pp 1-551

Domonik A (2003) Representation of joint surfaces of the Podhale Flysch sandstone in research on strength in selected exposures of the Podhale Basin. Przegląd Geologiczny 51:430-435 (in Polish with English summary)

Domonik A (2005) Geomechaniczna analiza powierzchni ciosowych w piaskowcach cergowskich z Komańczy. $\mathrm{PhD}$ thesis. Archive of the Faculty of Geology, University of Warsaw, pp 1-106

Domonik A (2007) Anisotropy of geomechanical properties of flysch sandstones as an effect of influence of stresses on example of cergowskie sandstones from Kamańcza. Gelogos 11:133-141 (in Polish with English summary)

Domonik A (2008) Textural rock anisotropy as a result of load memory exemplified by Cergowa sandstones from Komańcza. Geologija. https://doi.org/10.6001/geologija.v50ipriedas.1572

Domonik A (ed) (2012) Resistance and deformation rock properties. Part VI. Central Western Carpathians, Volume 13 and 14. Warsaw, Poland, Department of Geomechanics, Institute of Hydrogeology and Engineering Geology, Faculty of Geology, University of Warsaw, pp 1-126 (in Polish)

Donath FA (1961) Experimental study of shear failure in anisotropic rocks. Geol Soc Am Bull 72:985-989

Dunne WM, Hancock PL (1994) Paleostress analysis of small-scale brittle structures. In: Hancock PL (ed) Continental deformation. Pergamon Press, London, pp 101-120

Dziedzic A (2005) Ocena cech strukturalnych piaskowców krośnieńskich z Mucharza (Beskid Mały) na podstawie pomiarów prędkości ultradźwiękowej fali podłużnej. Przegląd Geologiczny 53(7):601-604

Eyinla DS, Oladunjoye MA (2014) Estimating geo-mechanical strength of reservoir rocks from well logs for safety limits in sand-free production. J Environ Earth Sci 4(20):38-43

Fodor L, Csontos L, Bada G, Gyorfi I, Benkovics L (1999) Tertiary Tectonic evolution of the Panonian basin system and neighbouring orogens: a new synthesis of palaeostress data. In: Durand B, Jolivet L, Horvath F, Serrani M (Eds) The Mediterranean Basins: tertiary extension within the Alpine Orogen, vol 156. Geological Society, London, pp 295-334

Furtak K (2004) Ocena przydatności metody sejsmicznej do projektowania tuneli. Geoinżynieria i tunelowanie 3:14-17

Gedl P (2000) Biostratygrafia i paleośrodowisko paleogenu Podhala w świetle badań palinologicznych. Część I. Stud Geol Pol 117:69-154

Gołąb J (1959) Zarys stosunków geologicznych fliszu zachodniego Podhala. Biuletyn Instytutu Geologicznego 149:225-237

Golonka J, Oszczypko N, Ślączka A (2000) Late CarboniferousNeogene geodynamic evolution and paleogeography of the circum-Carpathian region and adjacent areas. Ann Soc Geol Pol 70:107-136

Griffith AA (1921) The phenomena of rapture and flow in solids. Philosophical transactions of the Royal Society of London. Ser A Contain Paper Math Phys Charact 221:163-198. https://doi. org/10.1098/rsta.1921.0006

Gueguen Y, Schubnel A (2003) Elastic wave velocities and permeability of cracked rocks. Tectonophysics 370:163-176. https:// doi.org/10.1016/S0040-1951(03)00184-7

Halicki B (1963) The tectonics of Podhale. Ann Soc Geol Pol 33(3):349-362

Hancock PL (1985) Brittle microtectonics: principles and practice. J Struct Geol 7:437-457. https://doi. org/10.1016/0191-8141(85)90048-3

Helgeson DE, Aydin A (1991) Characteristic of joint propagation across layer interfaces in sedimentary rocks. J Struct Geol 13(8):897-911

Hooker JN, Laubach SE, Marrett R (2017) Microfracture spacing distribution and the evolution of fracture patterns in sandstones. $\mathbf{J}$ Struct Geol. https://doi.org/10.1016/j.jsg.2017.04.001

Jaeger JC (1960) Shear failure of anisotropic rocks. Geol Mag 97:65-72

Jaroszewski W (1972) Drobnostrukturalne kryteria tektoniki obszarow nieorogenicznych na przykładzie połnocno-wschodniego obrzeżenia mezozoicznego Gór Świętokrzyskich. Stud Geol Pol 38:1-216

Jaroszewski W (1974) Tektonika uskoków i fałdów. Wydawnictwa Geologiczne, Warszawa, pp 1-296

Kieslinger A (1958) Restspannung und Entspannung im Gestein. Geologie und bauwesen. Jhg, Wien, pp 95-112

Kłopotowska A, Łukasiak D (2017) Estimation of lithogenetic features of flysch sandstones based on ultrasonic tests. Przegląd Geologiczny 65(3):177-182

Książkiewicz M (1968) Observation on jointing in the Flysch Carpathians. Ann Soc Geol Pol 38:335-384 (in Polish with English summary)

Książkiewicz M (1972) Budowa geologiczna Polski. T. IV. Tektonika. Część 3. Karpaty. Wydawnictwa Geologiczne, Warszawa, pp $1-228$

Ludwiniak M (2006) Geometria i geneza sieci spękań ciosowych we fliszu zachodniego Podhala. PhD thesis. Archive of the Faculty of Geology. University of Warsaw, pp 1-94

Ludwiniak M (2008) Joint-network evolution in the western part of Podhale Flysch (Inner Carpathians, Poland). Przegląd Geologiczny 56(12):1092-1099 (in Polish with English summary) 
Ludwiniak M (2010) Multi-stage development of joint network in the flysch rocks of western Podhale (Inner Western Carpathians, Poland). Acta Geol Pol 60(2):283-316

Mandl G (1988) Mechanics of tectonic faulting: models and basic concepts. Elsevier, Amsterdam, pp 1-401

Mastella L (1972) Interdependence of joint density and thickness of layers in the Podhale flysch. Bulletin de l'Académie. Pol Sci 20:187-196

Mastella L (1988) Structure and evolution of Mszana Dolna window, Outer Carpathians, Poland. Ann Soc Geol Pol 50:53-173 (in Polish with English summary)

Mastella L, Klimkiewicz D (2008) Tektonika fliszu podhalańskiego w dolinie Białego Dunajca. Archiwum Instytutu Geologii Podstawowej UW, Warszawa

Mastella L, Konon A (2002) Jointing in the Silesian nappe (Outer Carpathians, Poland)—paleostress reconstruction. Geol Carpath 53:315-325

Mastella L, Mizerski W (1977) Geological structure of southwestern Podhale. Przegląd Geologiczny 25:494-499 (in Polish with English summary)

Mastella L, Ozimkowski W (1979) The tectonics of southeastern Podhale. Przegląd Geologiczny 27:387-393 (in Polish with English summary)

Mastella L, Zuchiewicz W (2000) Jointing in the Dukla Nappe (Outer Carpathians, Poland): an attempt at palaeostress reconstruction. Geol Quart 44:377-390

Mastella L, Ozimkowski W, Szczęsny R (1988) Tektonika północnozachodniej części fliszu podhalańskiego. Przegląd Geologiczny 36:566-572

Mastella L, Zuchiewicz W, Tokarski AK, Rubinkiewicz J, Leonowicz P, Szczęsny R (1997) Application of joint analysis for paleostress reconstructions in structurally complicated settings: case study from Silesian nappe, Outer Carpathians (Poland). Przegląd Geologiczny 45:1064-1066

Mastella L, Konon A, Szczęsny R (2000) Mapa geologiczna SW części fliszu podhalańskiego 1: 25,000. Archiwum Instytutu Geologii Podstawowej UW, Warszawa

Mockovčiaková A, Pandula B (2003) Study of the relation between the static and dynamic moduli of rocks. Metalurgija 42(1):37-39

Morawski W (1972) Tectonics of the northern limb of the Podhale synclinorium. Acta Geol Pol 22:573-592 (in Polish with English summary)

Mukherjee S (2011) Estimating the viscosity of rock bodies-a comparison between the Hormuz- and the Namakdan Salt Domes in the Persian Gulf, and the Tso Morari Gneiss Dome in the Himalaya. Indian J Geophys Union 15(3):161-170

Mukherjee S (2013) Channel flow extrusion model to constrain dynamic viscosity and Prandtl number of the Higher Himalayan Shear Zone. Int J Earth Sci 102:1811-1835. https://doi. org/10.1007/s00531-012-0806-z

Mukherjee S (2017a) Airy's isostatic model: a proposal for a realistic case. Arab J Geosci 10:268. https://doi.org/10.1007/ s12517-017-3050-9

Mukherjee S (2017b) Locating center of gravity in geological contexts. Int J Earth Sci. https://doi.org/10.1007/s00531-017-1560-z

Mukherjee S (2017c) Moment of inertia for rock blocks subject to bookshelf faulting with geologically plausible density distributions. Int J Earth Sci (in press)

Mukherjee S (2018) Locating center of pressure in 2D geological situations. J Indian Geophys Union 22(1):49-51

Mukherjee S, Mulchrone K (2012) Estimating the viscosity and Prandtl number of the Tso Morari Gneiss Dome, western Indian Himalaya. Int J Earth Sci 101:1929-1947. https://doi.org/10.1007/ s00531-012-0758-3
Mukherjee S, Talbot CJ, Koyi HA (2010) Viscosity estimates of salt in the Hormuz and Namakdan salt diapirs, Persian Gulf. Geol Mag 147(4):497-507. https://doi.org/10.1017/S001675680999077X

Murray FN (1967) Jointing in sedimentary rocks along The Grand Hogback monocline, Colorado. J Geol 75:340-350. https://doi. org/10.1086/627261

Najibi AR, Ghafoori GR, Lashkaripour MR, Asef MR (2015) Empirical relations between strength and static and dynamic elastic properties of Asmari and Sarvak limestones, two main oil reservoirs in Iran. J Petrol Sci Eng 126:78-82. https://doi.org/10.1016/j. petrol.2014.12.010

Olson JE (1993) Joint pattern development: effects of subcritical crack growth and mechanical crack interaction. J Geophys Res Atmos 981(B7):12251-12265. https://doi.org/10.1029/93JB00779

Oszczypko N, Ślączka A (1989) The evolution of the Miocene basin in the Polish Outer Carpathians and their foreland. Geol Carpath 40:23-36

Oszczypko N, Ślączka A, Żytko K (2008) Regionalizacja tektoniczna Polski - Karpaty zewnętrzne i zapadlisko przedkarpackie. Przegląd Geologiczny 56(10):927-935

Paterson MS (1958) Experimental deformation and faulting in Wombeyan marble. Geol Soc Am Bull 69:465-476

Paterson MS (1978) Experimental rock deformation - the brittle field. Springer, Berlin, pp 1-254

Pettijohn FJ, Potter PE, Siever R (1972) Sand and sandstone. Springer, Berlin, pp 1-618

Pinińska J (2011) Właściwości wytrzymałościowe i odkształceniowe skał Polski na dużych głebokościach w warunkach wysokiego ciśnienia i temperatury. Tom 12. Geomechaniki IHiGI Wydział Geologii UW, Warszawa, pp 1-193

Pinińska J, Dziedzic A (2006) Właściwości wytrzymałościowe i odkształceniowe skał 5/9. Region Lubelski. Katalog. Zakład Geomechaniki IHiGI Wydział Geologii UW, Warszawa, pp 1-97

Pinińska J, Domonik A, Dziedzic A, Łukasiak D (2015) The methodology of a complex engineering-geological approach to establish a geopark: case study of the Małopolska Wisła River Gorge. Geol Quart 59(2):408-418. https://doi.org/10.7306/gq.1181

Plašienka D, Grecula P, Putiš M, Kovač M, Hovorka D (1997) Evolution and structure of the Western Carpathians: an overview. In: Grecula P, Hovorka D, Putiš M (eds) Geological evolution of the Western Carpathians. Mineralia Slovaca, Monograph. Geological Survey of Slovak Republic, Bratislava, pp 1-24

Price NJ (1959) Mechanics of jointing in rocks. Geol Mag 96:149-167. https://doi.org/10.1017/S0016756800060040

Price NJ (1966) Fault and joint development in brittle and semi-brittle rock. Pergamon Press, Oxford, pp 1-176

Price NJ (1967) The tectonic significance of mesoscopic subfabric in the southern Rocky Mountains of Alberta and British Columbia. Can J Earth Sci 4(1):39-70. https://doi.org/10.1139/e67-003

Price NJ, Cosgrove JW (1990) Analysis of geological structures. Cambridge University Press, Cambridge, pp 1-502

Ramsay JG, Huber MI (1984) The techniques of modern structural geology, vol 1. Strain analysis. Academic Press, London, pp 1-307

Roniewicz P (1969) Sedimentation of the Nummulite Eocene in the Tatra. Acta Geol Pol 19:503-608 (in Polish with English summary)

Rubinkiewicz J (1996) Tectonics of the Dukla Overthrust Zone in the western part of Bieszczady. Przegląd Geologiczny 44(12):1199_ 1204 (in Polish with English summary)

Rubinkiewicz J (1998) Development of joints in Silesian nappe (Western Bieszczady, Carpathians, SE Poland). Przegląd Geologiczny 46(9):820-826 (in Polish with English summary) 
Savalli L, Engelder T (2005) Mechanisms controlling rapture shape during subcritical growth of joints in layered rocks. Geol Soc Am Bull 117(3-4):436-449

Shkuratnik VL, Nikolenko PV, Kormnov AA (2015) Ultrasonic correlation logging for roof rock structure diagnostics. Geomechanics 51(3):456-461. https://doi.org/10.1134/S1062739115030059

Śmigielski M (2007) Analiza spękań ciosowych w południowowschodnim fragmencie Centralnego Synklinorium Karpackiego. Metodyka i zastosowanie. PhD thesis. Archive of the Faculty of Geology. University of Warsaw, pp 1-123

Środoń J, Kotarba M, Biroň A, Such P, Clauer N, Wójtowicz A (2006) Diagenetic history of the Podhale Orava Basin and the underlying Tatra sedimentary structural units (Western Carpathians): evidence from XRD and K-Ar of illite-smectite. Clay Miner 41:751-774. https://doi.org/10.1180/0009855064130217

Stan-Kłeczek I (2016) The study of the elastic properties of carbonate rocks on a base of laboratory and field measurement. Acta Montanistica Slovaca 21(1):76-83

Stan-Kłeczek I, Idziak AF (2008) Anisotropy of elastic properties of rock mass induced by cracks. Acta Geodyn Geomater 5(2/150):153-159

Stan-Kłeczek I, Idziak AF (2013) Study of the relation between cracks and the elastic properties of rock mass. In: Kwaśniewski M, Łydżba D (eds) Rock mechanics for resources, energy and environment. Eurorock 2013, Taylor \& Francis Group, London, Great Britain, pp 157-160

Stan-Kłeczek I, Sutkowska K, Stan D, Zolich M (2012) The study of the relationship between cracks and seismic parameters of rocks. Acta Geodyn Geomater 9(2/166):137-142

Stupnicka E (1997) Geologia regionalna Polski. Wydawnictwa Geologiczne, Warszawa, pp 1-346

Szichin JS (1960) K woprosu o mechanizmie obrazowania skoływych naruszenij. In Problems of Tectonophysics. Gosgeoltekhizdat. Moscow (in Russian)
Thiel K (1980) Mechanika skał w inżynierii wodnej. Warszawa. Państwowe Wydawnictwo Naukowe, pp 1-336

Twiss RJ, Moores EM (2001) Structural geology. WH Freeman and Comp, New York, pp 1-532

Van der Pluijm BA, Marshak S (2004) Joints and veins. In: Earth structure: an introduction to structural geology and tectonics. 2nd edn. WW Norton \& Company, New York, London, pp 138-165

Vilhelm J, Rudajev V, Živor R, Lokajicek T, Pros Z (2010) Influence of crack distribution of rocks on P-wave velocity anisotropy-a laboratory and field scale study. Geophys Prospect 58(6):10991110. https://doi.org/10.1111/j.1365-2478.2010.00875.x

Watycha L (1959) Uwagi o geologii fliszu podhalańskiego we wschodniej części Podhala. Przegląd Geologiczny 7:350-356

Watycha L (1968) Wstępna ocena warunków i możliwości powstawania ropy naftowej w utworach wschodniej części fliszu podhalańskiego. Kwartalnik Geologiczny 12:898-915

Watycha L (1976) Szczegółowa Mapa Geologiczna Polski. 1:50 000. Arkusz Czarny Dunajec (1048). Wydawnictwa Geologiczne, Warszawa

Watycha L (1977) Objaśnienia do Szczegółowej Mapy Geologicznej Polski. 1:50 000. Arkusz Czarny Dunajec. Wydawnictwa Geologiczne, Warszawa

Żelaźniewicz A, Aleksandrowski P, Buła Z, Karnkowski PH, Konon A, Oszczypko N, Ślączka A, Żaba J, Żytko K (2011) Regionalizacja tektoniczna Polski. KNG PAN, Wrocław, pp 1-60

Živor R, Vilhelm J, Rudajev V, Lokajicek T (2011) Measurement of $\mathrm{P}$ - and $\mathrm{S}$-wave velocities in a rock massif and its use in estimation elastic moduli. Acta Geodyn Geomat 8(2):157-167

Zoetemeijer R, Tomek Č, Cloetingh S (1999) Flexural expression of European continental lithosphere under the western outer Carpathians. Tectonics 18:843-861. https://doi.org/10.1029/199 8TC900034 